\title{
Implementation and constraints of of the use of farmer's card in increasing the effectiveness of subsidized fertilizer distribution in Ciamis and Pati District
}

\author{
Wahyudi $^{1}$, Imam Mujahidin Fahmid $^{2}$, Darmawan Salman ${ }^{2}$, Sultan Suhab ${ }^{3}$, Adang \\ Agustian ${ }^{4,}$, , Sri Hery Susilowati ${ }^{4}$, Sumedi ${ }^{4}$, and Rangga D. Yofa ${ }^{4}$ \\ ${ }^{1}$ Hasanuddin University Doctoral Program Students, and as staff in the Planning Bureau-Ministry of \\ Agriculture, Indonesia \\ ${ }^{2}$ Professor of Hasanuddin University, Makassar, Indonesia \\ ${ }^{3}$ Lecturer of Hasanuddin University, Makassar, Indonesia \\ ${ }^{4}$ Researcher at the Indonesian Center for Agricultural Socio-Economic Policy, Indonesia
}

\begin{abstract}
The subsidized fertilizer distribution policy is still facing various problems. The government continues to make efforts to improve it, including through the farmer's card mechanism. The research aims to analyze the development and problems of implementing farmer's card, as well as formulating strategies to improve the implementation of farmer's card. The study was conducted in Ciamis and Pati didtrict, 2019. The data collected includes primary data from interviews with 30 rice farmers, 4 kiosks and 2 fertilizer distributors, and secondary data from the Agriculture Office of the research location. Data analysis was carried out quantitatively and descriptively qualitatively. The results showed that the process of printing the farmer's card in Ciamis and Pati Regencies respectively $99.75 \%$ and $74.0 \%$ of the total proposed farmer's card. The problems faced in the application of the farmer's card are the incomplete data of farmers in the eDPFGN, the improvement of data on land tenure for each planting season, and the limited availability of EDC equipment at each fertilizer kiosk. To improve the fertilizer distribution system through the farmer's card, it is necessary to improve the validation of the eDPFGN data, infrastructure support and human resources at the fertilizer kiosk and farmer group level.
\end{abstract}

\section{Introduction}

In order to encourage an increase in agricultural production, especially national rice, the government provides fertilizer subsidies so that the price of fertilizer circulating in the market does not burden farmers. Fertilizer subsidies are provided through a fertilizer selling price mechanism. In addition, the government also continues to encourage the efficient use

*Corresponding author: aagustian08@gmail.com 
of fertilizers through policies related to supply and distribution, as well as prices through subsidies. Various studies $[1,2]$ reveal that the existence of a fertilizer subsidy policy aims to encourage an increase in agricultural production.

Based on the results of the study of Suryana et al. (2015) [3] stated that currently there are still some problems in the distribution of subsidized fertilizers in the field. These problems include: (1) In terms of planning, the allocation of subsidized fertilizers as outlined in the Regulation of the Minister of Agriculture is much lower than the needs proposed by local governments, so that it often leads to scarcity; (2) There is a moral hazard in the field, due to the large price difference (more than 50\%) between the price of subsidized fertilizer and the price of non-subsidized (commercial) fertilizer that is traded in the market; (3) Not all farmers become members of farmer groups, so that farmers' fertilizer needs are not entirely included in the proposed electronic - Definitive Plan for Group Needs (eDPFGN); and (4) Farmer data contained in the eDPFGN is generally not accurate, especially regarding data on land area and cropping patterns.

In order to increase effectiveness and increase benefits optimally, the input of the fertilizer must reach the farmers with the right six principles, namely: the right amount, dose, type, price, quality, and on time. Therefore, the government continues to make efforts to improve the distribution system of subsidized fertilizers, which includes the mechanism for using the farmer's card. On the farmer's card, each farmer will get information on the quota of subsidized fertilizers according to the area of land he manages and the cropping pattern he does.

Therefore, to support the implementation of the farmer's card, the farmer data entry entered in the eDPFGN must continue to be completed and improved. According to information from the Coordinating Ministry for the Economy in 2020, it is currently targeted that the implementation of farmer's card in Java and Madura can reach 65 percent of the volume allocation for subsidized fertilizers for 2020, while outside Java, data and the process of printing farmer's card are still being carried out. It is hoped that in the future with the presence of the farmer's card, the distribution chain of subsidized fertilizer will be more efficient and effective until it reaches the target farmers [4].

Based on the description above, this study aims to analyze: (1) the development of the implementation of the farmer's card, (2) the problems in the implementation of the farmer's card, and (3) the strategy for increasing distribution effectiveness through the implementation of the farmer's card.

\section{Methodology}

\subsection{Theoretical framework}

The current fertilizer subsidy is a price subsidy, where the subsidy funds are given to fertilizer factories. According to [5] that subsidies are the opposite or opposite of taxes. Subsidies given to the production/sale of an item cause the selling price of the item to be lower. According to the results of research by $[6,7,8]$ fertilizer subsidy is a government intervention policy to help small farmers through the provision of cheap fertilizers.

However, the distribution of subsidized fertilizers is still colored by the issue of scarcity which causes the price to be above the highest retail price, for example in Riau Province [9]. Furthermore, the research results of [10] that one of the problems faced in the distribution of subsidized fertilizers is that there is still seepage of the use of subsidized fertilizers into sectors that should not be entitled to use subsidized fertilizers, due to the wide price disparity between subsidized fertilizers and non-subsidized fertilizer prices. Therefore, the use of the farmer's card is a solution to increase the effectiveness of the 
distribution of subsidized fertilizers, so that subsidized fertilizers are only used by farmers who are entitled to receive them. This is as revealed by the research results of $[11,12,13]$ that the implementation of the farmer's card has a significant effect on the effectiveness of the distribution of subsidized fertilizers. Thus, the distribution pattern of subsidized fertilizers has used information technology as well as digital, and this has been studied by researchers $[14,15,16,17]$.

Farmer's card is a system designed to increase the accuracy of distribution of subsidized fertilizers to farmers. The source of data on the farmer's card comes from the data inputted by the farmer's group on the eDPFGN. On the farme's card, every farmer who has registered with the eDPFGN will receive a number of fertilizer quota information according to the area of land and the cropping pattern he cultivates. The card is similar to a debit card that is shown and swiped at the Electronic Data Capture machine at the official kiosk of subsidized fertilizer. With the existence of the farmer's card, the government will be able to accurately measure the number of farmers and the amount of fertilizer needed. So that the distribution of subsidized fertilizers will be more targeted and efficient.

Farmers who are considered entitled to have a farmer's card, based on the general requirements, are farmers who own land, farmers who own land as well as cultivators, and sharecroppers, and farm laborers do not get it. For the area of land, a maximum of 2 hectares is set with the standard of the Identity Card, and in the occupation column listed is the farmer.

In Central Java Province, according to [18], farmer's card is a co-branded BRI debit card that is used specifically to read the allocation of subsidized fertilizer and subsidized fertilizer payment transactions in BRI's electronic data capture machine, placed at retailers and can function to carry out all banking transactions in general.

\subsection{Data types and data sources}

This research was conducted in Ciamis district, West Java and Pati district, Central Java, in 2019. The types of data collected include primary and secondary data. Primary data was collected using a survey method, namely by interviewing 30 rice farmers, 4 official kiosks distributing subsidized fertilizers and 2 distributors of subsidized fertilizers in two research locations. In addition, secondary data was also collected from the Food Crops Agriculture Office in the research location, as well as from the Directorate General of Agricultural Infrastructure and Facilities, Jakarta.

\subsection{Data analysis}

In this study, after primary and secondary data were collected, they were analyzed quantitatively and qualitatively. Quantitative analysis was carried out by calculating the percentage of data on the number of farmer's card that had been printed and distributed to farmers, and qualitative analysis was carried out with sources from deepening information at the research location.

\section{Results and discussion}

\subsection{The development of the implementation of the farmer's card}

Farmers' cards must be owned by farmers in order to get subsidized fertilizers. Not only can it read subsidized fertilizer allocations and transactions, this card can also be used in general banking transactions such as receiving and transferring money. In the future, it is 
hoped that not only fertilizer subsidies will be focused on this card, but also quality seeds. The Ministry of Agriculture will use the farmer's card as a complete data set as the basis for policy making. Farmer's Card is an integrated banking service access facility that functions as savings, transactions, lending to subsidized cards (e-wallet). Therefore, the advantages of farmer's card include single data entry, online, transparent, and multifunctional tiered validation processes.

As of March 2019, 7,418,820 farmer's card has been printed nationally. Of this amount, 5,512,504 farmer's card has been distributed, and about 469,191 farmers's card have been used to find out (swipe) the fertilizer quota obtained by the farmers concerned. Until 2019, there were only 7 printed farmer's card available in 7 provinces, namely: West Java, Central Java, East Java, Banten, DI Yogyakarta, Bali, and South Sulawesi (Table 1).

Table 1. Development of the number of farmer's card (FC) in 7 Provinces in Indonesia, Until March 2019.

\begin{tabular}{|l|l|c|c|c|c|c|c|c|}
\hline No & Provinsi & $\begin{array}{c}\text { Num.of } \\
\text { farmer's } \\
\text { card (data } \\
\text { eDPFGN) }\end{array}$ & $\begin{array}{c}\text { Kiosk } \\
\text { insta-1led } \\
\text { EDC }\end{array}$ & $\begin{array}{c}\text { Kiosk } \\
\text { No } \\
\text { EDC }\end{array}$ & $\begin{array}{c}\text { FC } \\
\text { Printed }\end{array}$ & $\begin{array}{c}\text { FC } \\
\text { injected } \\
\text { data } \\
\text { eDPFG } \\
\text { N }\end{array}$ & $\begin{array}{c}\text { FC distri- } \\
\text { buted }\end{array}$ & $\begin{array}{c}\text { FC } \\
\text { Used }\end{array}$ \\
\hline 1. & West Java & $1,269,293$ & 184 & 442 & $1,365,412$ & 717,073 & 861,290 & - \\
2. & Central Java & $1,522,658$ & 4,702 & - & $2,882,054$ & - & $2,466,869$ & 428,864 \\
3. & East Java & $1,562,012$ & 5,453 & 772 & $2,455,787$ & 89,010 & $1,703,580$ & 40,327 \\
4. & Yogya & 45,543 & 172 & - & 284,090 & - & 279,741 & - \\
5. & Banten & 168,360 & 249 & - & 206,527 & - & 196,953 & - \\
6. & Bali & 108,260 & 31 & 43 & 7,768 & 7,768 & 4,061 & - \\
7. & S. Sulawesi & 456,130 & 253 & 99 & 217,182 & 158,687 & 10 & - \\
& Total & $5,132,256$ & 11,044 & 1,356 & $7,418,820$ & 972,538 & $5,512,504$ & 469,191 \\
\hline & National & $6,887,569$ & 11,063 & 1,983 & $7,418,820$ & 972,538 & $5,512,504$ & 469,191 \\
\hline
\end{tabular}

Source: [19].

Bank Mandiri is set to distribute fertilizer subsidies through farmer's card to more than 800,000 farmers from around 3 million farmers in West Java. In Ciamis district, in terms of the process of collecting data and distributing farmer's card since 2018/2019, which begins with collecting data on farmers by Field Agricultural Extension Officers (FAE). Furthermore, the farmer data was submitted to the Agricultural Extension Center (AEC) for verification and validation, and the results of the verification reached 1,984 farmer groups and there were 127,878 people. Then the results are submitted to the District Agriculture and Food Security Service for verification and validation. If the data is still incomplete, then the data will be requested to be completed by the AEC. Furthermore, there were 126,782 farmers who were proposed to get farmer's card, and for the printed farmer's card as many as 126,465 units. Of these, 113,377 farmer's card have been distributed, 12,060 farmer's card have not been collected, 1,041 farmer's card where the farmer died and the rest were not taken for other reasons. Thus, the progress of card printing from the proposal has reached $99.75 \%$.

Table 2. Description of the development of farmer's card (FC) printing and distribution in Ciamis Regency, West Java, 2019.

\begin{tabular}{|c|l|c|c|}
\hline Num. & \multicolumn{1}{|c|}{ Deskription } & \multicolumn{2}{|c|}{ Realization } \\
\cline { 3 - 4 } & & amount & $\%$ \\
\hline 1. & Proposed FC (farmers) & 126,782 & - \\
2. & Printed FC & 126,465 & 99.75 \\
3. & Ditributed FC & 113,337 & 89.40 \\
4. & Uncollected FC and others & 13,128 & 10.35 \\
\hline
\end{tabular}

Source: [20]

Note: Percent of the proposal for the farmer's card. 
Until now, system improvements and e-DPFGN validation have been carried out for the distribution of subsidized fertilizers. So that later subsidized fertilizers can be more targeted and synchronized with the database used for farmer's card. Farmers who do not have a farmer's card will not be allowed to buy subsidized fertilizer in the future. However, if it has been registered in the eDPFGN, even though they do not have a farmer's card, farmers can still buy subsidized fertilizers and then the farmer's card will still be made.

Based on the information obtained, in terms of subsidized fertilizer distribution, namely the purchase of fertilizer by farmers at official kiosks, there are 2 fertilizer redemption systems with Farmer Cards: (1) Redemption independently, and (2) Redemption in groups/collectively. On redemption independently, each farmer must bring a farmers's card to be swiped at the purchase of fertilizer at the official kiosk, paid directly and in cash. In addition, farmers are also required to remember or carry a farmer's card PIN. Meanwhile in the group system, where the PIN is written by the group then swiped by the group leader and the fertilizer will be transported by the group. In the group system, payment for fertilizer to the kiosk is usually funded first by the group treasury. Thus, this system requires that farmer groups have cash funds. Payment for fertilizer purchases by farmers can be in cash or pay for harvest. The harvest payment system will usually have additional costs besides transportation costs as well as interest for the group and group cash.

The average land tenure in the study area of Ciamis district, West Java, ranges from 0.14 - 1 ha. The system of buying and selling and leasing /land acquisition is also quite dynamic, so that in the future it will be a challenge in printing farmer's card. Currently updated eDPFGN is carried out once a year, and that also requires extra energy and costs quite a bit. Meanwhile, the cost for updating is not yet available adequately.

In collecting data on farmers for the requirements for the farmer's card, there are often obstacles, for example in the statement of the land certificate often the land has changed, for example from rice fields to dry land. When the farmer's card has been printed, and the farmer's card is used, as soon as it is swiped, a fertilizer quota for a year appears, and farmers who do not understand will redeem all of the fertilizer quota. Purchasing fertilizer at the kiosk, farmers also often forget their PIN or even their farmer's card is not carried, so that it can cause tension between farmers and the fertilizer kiosk. Meanwhile, in areas bordering other regencies where the regencies have not yet implemented the farmer's card, farmers in the Ciamis district will easily buy subsidized fertilizer at kiosks that do not require a farmer's card. This happened, because the use of the farmer's card was not yet compact in all districts in West Java. This is also a problem for official fertilizer kiosks, which already require a farmer's card to sell their fertilizers. Farmers will buy fertilizer according to the quota they get, and this is done at the kiosk where the farmer's name is listed in the eDPFGN held by the kiosk. If the amount of fertilizer purchased by the farmer as stated in the farmer's card is deemed insufficient, then the farmer can buy the shortage in the form of non-subsidized fertilizer at a higher price.

According to the official Kiosk in Ciamis district, currently subsidized fertilizers are only available at official kiosks. The fertilizer kiosk has a sales target and must be met, and if it is not achieved, a warning from the fertilizer distributor will be given. With a thin marketing margin, and a tight system, it is seen as a special difficulty for fertilizer stalls.

In Pati district, Central Java, the farmer's card program has not been running effectively since it was implemented for the past year. Data from the Office of Agriculture and Plantation of Central Java, of the 2,429,371 cards that have been distributed to farmers, only about 450,000 have been used effectively or around $18 \%$. The farmer's card has started running and there is still room for improvement together. Correction of data collection is carried out on the 25-30th of each month. 
One of the benefits of the farmer's card is to ensure that farmers get their rights, namely subsidized fertilizer in accordance with what the state provides. Based on data from the Office of Agriculture and Plantation of Central Java, that the total farmers in Central Java are around 2,876,511 farmers. of this number, $1,524,368$ people or about $84.27 \%$ are included in the list of land-owning farmers.

According to the Office of Agriculture and Plantation, the existence of the farmer's card program makes it easier for the Central Java Provincial Government to collect agricultural data in its area. However, there are still many weaknesses, including data collection for farmers who own lands larger than 2 hectares, still receiving subsidies or not being targeted. With the presence of farmer's card, decision making related to agricultural policy in Central Java will be more precise. With the farmer's card, the Central Java Provincial Government can see the level of production, so that later it will be easy to implement policies and see the current condition and distribution of production. This is because with the availability of fertilizer at the farmer level, it is hoped that the target for increasing production is achieved. This is as studied by several researchers $[21,22]$ that the availability of fertilizers, especially subsidized fertilizers will encourage increased production.

In Pati Regency, the number of existing farmers reaches 134,000 farmers. Farmers' cards that have been printed have reached 98,900 farmer's card, while farmers who have BRI accounts are 99,400 farmers. Furthermore, the farmer cards that have been handed over to farmers are 83,400 farmer's card. The existence of farmer's card that was not taken was caused by the following factors: (a) The disappointment of farmers, where their hopes for farmer's card were filled with money so that farmers who had not taken farmer's card were lazy to take farmer's card quickly, (b) The possibility of farmers changing their address or working out of town, (c) Because farmers who get farmer's card work outside the city, while taking farmer's card cannot be authorized.

Table 3. Description of the development of farmer's card (FC) printing and distribution in Pati Regency, Central Java, 2019.

\begin{tabular}{|c|l|c|c|}
\hline Num. & \multicolumn{1}{|c|}{ Deskription } & \multicolumn{2}{|c|}{ Realization } \\
\cline { 3 - 4 } & & amount & $\%$ \\
\hline 1. & Proposed FC (farmers) & 134,000 & - \\
2. & Printed FC & 98,00 & 74.00 \\
3. & Ditributed FC & 83,400 & 62.24 \\
4. & Uncollected FC and others & 15,500 & 11.76 \\
\hline
\end{tabular}

Source: [23].

Note: Percent of the proposal for the farmer's card.

\subsection{Problems in the Implementation of farmer's card}

In Ciamis district - West Java, the problems faced in printing and using farmer cards, according to [20], include: (1) The specifications of data processing equipment in the District and Regency are less supportive for the Application program eDPFGN; (2) Not all Agricultural Extension Centers that serve as places to repair eDPFGN have internet networks; (3) Farmer data at the field level is still different from the data from the Population and Civil Registration Service, and currently improvements are still being made; (4) Many official fertilizer kiosks do not have permanent EDC operators; (5) There are still farmers whose data has not been accommodated in the e-DPFGN system; and (6) There are still official fertilizer kiosks that serve the sale of subsidized fertilizers without farmer's card requirements. 
Furthermore, in Central Java Province, the implementation of the farmer's card currently has several problems, including: (1) Currently, the workload on Agricultural Extension Officers for implementing the farmer's card is very heavy, while the operational costs of the officers are not sufficient; (2) Technical problems if there is a change in commodities or change groups are seen as new participants in making farmer's card; (3) Fertilizer allocation so that NPK fertilizer needs to be increased; and (4) Delegation of authority in the opening of farmer's card data can be delegated.

In addition, according to the Pati district Agriculture Office, in the current use of the farmer's card farmer's card, there are still a number of problems that need to be handled in an integrated manner. The problems include: (1) The existence of discrepancies in the data on eDPFGN and Indonesian Food Management System owned by Bank BRI; (2) There are still farmers who have not been included in the membership of farmer groups; (3) Farmer's Card must be received according to the name of the owner and cannot be represented; (4) The difficulty of farmers remembering the PIN of the farmer's card provided by the Bank; (5) Some official fertilizer kiosks do not yet have EDC and the EDC signal also generally often encounters problems; (6) There is still see page of subsidized fertilizer from other regencies (especially in border areas); (7) Fertilizer allocation in Pati Regency is still far from eDPFGN, for example, SP36 fertilizer allocation is only around $26.71 \%$, and NPK is only around $35.85 \%$ of the need; and (8) The data listed on the farmer's card is the data on the eDPFGN application.

\subsection{Strategy for increasing distribution effectiveness through the implementation of farmer's cards}

The farmer's card is a transaction tool in the form of a debit card that can be used to buy subsidized fertilizer by farmers who have been registered in farmer groups and are included in the eDPFGN. One of the requirements for obtaining a farmer's card is the owner/cultivator with a cultivated area of not more than two hectares.

To change indirect subsidies to be direct to farmers using farmer's card that refer to the eDPFGN there are several strategies that must be prepared, which include: (1) Regulations on fertilizer allocation at the provincial and district levels related to sub-sectors with more accurate allocation data; (2) Readiness of human resources (HR) at each level (distributors, kiosks, and farmer groups); (3) Availability of infrastructure, computer systems integrated with EDC (Electronic Data Capture) machines and farmer's card; (4) The need for a strategy to update farmers' data both with land area and cropping patterns they cultivate, given the dynamics of the arable land tenure system; and (5) There is a gradual change in policy, considering that fertilizer subsidies for farmers are very much needed in order to encourage agricultural productivity.

In Central Java Province, the activities carried out regarding the planning, allocation and distribution of fertilizers are at the food crops agriculture service. Efforts to prepare farmer group member data input into the Indonesian Food Management Information System (IFMIS), need to be continued and improved. This process is carried out by extension workers at the sub-district level using the identity of the Population Identification Number (PIN), name, area of land owned and/or cultivated, as well as data on fertilizer needs per farmer for food crops, horticulture, aquaculture, and smallholder plantations.

Within the framework of improving the implementation of the farmer's card, there are strategies that need to be taken, including: (1) The need for an integrated and flexible adjustment of the system designed in IFMIS that can accommodate quickly if there is a reallocation of fertilizer needs, (2) The need for improving signal conditions between urban areas and villages which are currently relatively different, (3) The need for education at the 
farmer level to carry out saving activities to buy fertilizer, (4) The need for thinking that there is an instrument for the farmer's card application that is not PIN-based, for example with finger identification or others, and (5) The need for gradual implementation of policies on the use of farmer's card in accordance with the readiness of human resources, infrastructure and the existing banking system.

\section{Conclusions and recommendations}

In the future, farmer's card must be owned by farmers so that they can get subsidized fertilizers. Not only can it read subsidized fertilizer allocations and transactions, the farmer's card can also be used in general banking transactions. The farmer's card can be a means of accessing integrated banking services that function as deposits, transactions, lending to subsidized cards (e-wallet). Therefore, the advantages of farmer's card include: single data entry, online, transparent, and multifunctional tiered validation processes.

Nationally, until Quarter 1 of 2019, 7.42 million unit of farmer's card have been printed. Of this amount, 5.51 million unit (74.3\%) have been distributed, and about 469,191 unit $(6.3 \%)$ have been used to determine the fertilizer quota obtained by the farmers concerned. The printed farmer's card are found in the following provinces: West Java, Central Java, East Java, Banten, DI Yogyakarta, Bali, and South Sulawesi.

In Ciamis district, West Java and Pati district, Central Java, the process of printing farmer's card has reached $99.75 \%$ and $74.0 \%$ of the total farmers in the RDKK, respectively.

The problems faced in the application of the farmer's card include: incomplete data on farmers in the eDPFGN, not updating data on the area of land tenure for each planting season, and the limited availability of EDC (Electronic Data Capture) tools at each fertilizer kiosk. To improve the fertilizer distribution system through the farmer's card, it is necessary to improve the validation of the eDPFGN data, infrastructure support and human resources at the fertilizer kiosk and farmer group level.

In order to improve the efficiency of distribution of subsidized fertilizers, the farmer's card will be used as a whole. Currently, not all districts in Indonesia print farmer's card, considering that the data collection system for the eDPFGN is still not complete. Therefore, the improvement of the eDPFGN system and validation must be carried out to support the distribution of subsidized fertilizers. So that later subsidized fertilizers can be more targeted.

\section{References}

1. V. Theriault, M. Smale. 2021. J. Food Policy 102 [2021].

2. H. Kuntyastuti, Sutrisno, SAD. Lestari. 2020. J. Degrade. Min. Land Manage 8, 1 [2020].

A. Suryana, A. Agustian, dan R.D. Yofa. 2015. Laporan Hasil Penelitian Analisis Kebijakan Pusat Sosial Ekonomi dan Kebijakan Pertanian, Bogor [2015].

3. Merdeka.com.. Realisasi Kartu Tani Hanya 12 Persen dari Target 65 Persen di Jawa dan Madura [2021].

4. R.S. Pindyck, D.L Rubinfeld. 2015. Microeconomics Saddle River New Jersey 07458 [2015].

5. W.R Susila. J. JP3 292 [2020]. 
6. A.M. Komareka, S. Drogue, R. Chenoune, J. Hawkins, S. Msangi, H. Belhouchette, G. Flichman. J. Agricultural Systems 154 [2017].

7. H. Takeshima, L.S.O.L. Tasie. 2015. J. Food Policy 54 [2015].

8. R. Nizar, A. Ariyanto. J. Pekbis 81 [2016].

9. P.U. Hadi, S.H. Susilowati, M. Rahmat, Supriyati. 2010. Hasil Uji Coba Penerapan Mekanisme Subsidi Pupuk Langsung ke Petani di Kabupaten Karawang, [2010].

10.L. Chakim , A. Rifin, B. Sanim. 2019. Pengaruh Implementasi Kartu Tani terhadap Efektivitas Penyaluran Pupuk Bersubsidi di Kabupaten Kendal, Jawa Tengah, 12p, [2019].

11. Susanawati, Indardi, A.W. Pangestika. Rice farmer perception of farm cards utilization in Pekalongan Regency, Central Java, Indonesia. ICSARD IOP Conf. Series: Earth and Environmental Science 250 [2019].

12. A.A. Coker. J. Trop. Agric. 132 [2014].

13.D. Pivoto, P.D. Waquil, E. Talamini, C.P.S. Finocchio, V.F.D. Corted, G.de.V. Mores. J. Information Processing in Agriculture 5 [2018].

14.L. Wiseman, J. A. Sanderson, E. Jakku. 2019. NJAS - Wagening. J. Life Sci. 90-91 [2019].

15. M. Shinde, K. Ekbote, S. Ghorpade, S. Pawar, S. Mone. 2016. Int. J. comput. sci. inf. technol. res. 7, 2, [2016].

16.C.C. Chibbompa, Impact of e-voucher farmer input support programme (FISP) on crop productivity and income diversification among small scale farmers of Lukanda Agricultural Camp in Kapiri Mposhi District in Zambia, 868p [2018].

17. Biro Infrastruktur Daerah Jawa Tengah, Buku Petunjuk Praktis Penggunaan Kartu Tani Melalui Sistem Informasi Pertanian Indonesia (SINPI) di Jawa Tengah, [2021].

18. Direktorat Pupuk dan Pestisida, Direktorat Jenderal Prasarana dan Sarana Pertanian. 2019. Perkembangan Data Kartu Tani, [2019].

19. Dinas Pertanian Tanaman Pangan Kabupaten Ciamis, Jawa Barat. Perkembangan Data Kartu Tani di Kabupaten Ciamis Jawa Barat, [2019].

20.S.R Singh, D. K Kundu, P.Dey, P. Singh and B.S. Mahapatra. J. Agric. Sci. 1562 [2018].

21.E.T. Jaja and L.I. Barber. J. of Biology, Agriculture and Healthcare, 71 [2017].

22. Dinas Pertanian Tanaman Pangan Kabupaten Pati, Jawa Tengah. Perkembangan Data Kartu Tani di Kabupaten Pati. Jawa Tengah, [2019]. 